This item is the archived peer-reviewed author-version of:

\title{
Foreign aid, education and lifelong learning in Africa
}

\section{Reference:}

Asongu Simplice A., Tchamyou Vanessa Simen.- Foreign aid, education and lifelong learning in Africa Journal of the knowledge economy - ISSN 1868-7865 - (2017), p. 1-21

Full text (Publisher's DOI): http://dx.doi.org/doi:10.1007/S13132-017-0449-1

To cite this reference: http://hdl.handle.net/10067/1419500151162165141 


\title{
Foreign aid, education and lifelong learning in Africa
}

\author{
Forthcoming in: Journal of the Knowledge Economy. \\ DOI: $10.1007 / \mathrm{s} 13132-017-0449-1(2016)$ \\ Simplice A. Asongu \\ African Governance and Development Institute, \\ P.O. Box 8413 \\ Yaoundé, Cameroon. \\ E-mail: asongusimplice@yahoo.com \\ Vanessa S. Tchamyou \\ Faculty of Applied Economics, \\ Stadscampus, Prinsstraat13, 2000 Antwerp, \\ University of Antwerp, Belgium \\ E-mail: Vanessa.SimenTchamyou@student.uantwerpen.be
}

\begin{abstract}
This study investigates the effect of foreign aid on education and lifelong learning in 53 African countries for the period 1996-2010. Three main issues are assessed, notably: (i) the effect of aid on education; (ii) the incremental impact of aid on education and (iii) the effect of aid on lifelong learning. Lifelong learning is measured as the combined knowledge acquired during the primary, secondary and tertiary levels of education. Foreign aid dynamics include: Total aid, aid from Multilateral Donors (MD) and aid from the Development Assistance Committee (DAC) countries. The empirical evidence is based on an endogeneity-robust Generalized Method of Moments. The following findings are established. First, the aid variables have positive effects on primary school enrolment and lifelong learning, with the exception of aid from MD which positively affects only lifelong learning. Second, the positive effect on primary school enrolment consistently has a higher magnitude compared to the corresponding impact on lifelong learning. Third, the effects of aid dynamics on secondary and tertiary school enrolments are not significant. We also contribute to the literature by proposing an indicator of lifelong learning for developing countries.
\end{abstract}

JEL Classification: I20; I28; F35; O55; P16 
Keywords: Lifelong learning; Foreign aid; Development; Africa

\section{Introduction}

The globalisation phenomenon is today an ineluctable process which can be ignored only by sacrificing the progress of nations. It has been become abundantly clear that for nations to be competitive and involved with the global economy, they have to keep-up with the rules of competition that characterise globalisation. Competition in the twenty-first century is substantially centred on knowledge economy (KE), which has been a key theme in World Bank and the Organization of Economic Co-operation and Development (OECD) reports since the beginning of the third millennium (Tchamyou, 2015). These dynamics of KE have been well understood by developed countries (e.g., Europe and North America) which are inexorably charting the pattern of development in the international arena. In calculated steps, Asia and Latin America have been increasingly articulating $\mathrm{KE}$ in their implementation of regional and national programs (Dahlman, 2007; Chandra \& Yokoyama, 2011). The pattern of the Japanese KE has set the course for Malaysia, China and the Newly Industrialized Economies of Asia (Singapore, Taiwan, Hong Kong and South Korea), which have been experiencing a remarkable transition from 'product-based economies' to 'knowledge-based economies'.

In light of the above, there has been growing interest in the relevance of KE in developing countries, especially those in Africa: a continent which has been documented to be lagging substantially in terms of KE relative to other regions of the world (Anyanwu, 2012). Currents in this stream of KE literature have included, inter alia: (i) general discourses on KE (Aubert, 2005; Rooney, 2005; Lin, 2006; Makinda, 2007; Anyanwu, 2012); (ii) education (Weber, 2011; Kamara et al., 2007; Amavilah, 2009; Ford, 2007; Oluwatobi \& Olurinola, 2015); (iii) indigenous knowledge systems (Lwoga et al., 2010; Raseroka, 2008); (iv) communication and information technologies (Maurer, 2008; Jonathan \& Camilo, 2008; Aker \& Mbiti, 2010; Ondiege, 2010; Chavula, 2010; Merritt, 2010; Butcher, 2011; Thacker, \& Wright, 2012; Penard et al., 2012; Demonbynes \& Thegeya, 2012; Asongu, 2013a, 2014a); (v) economic incentives and institutional regime (Andrés \& Asongu, 2013a; Cogburn, 2003; Letiche, 2006); (vi) innovation (Oyelaran-Oyeyinka \& Sampath, 2007; Carisle et al., 2013; Oluwatobi et al., 2014); (vii) intellectual capital and economic development (Wagiciengo \& Belal, 2012; Preece, 2013); (viii) research and development (Sumberg, 2005; German \& Stroud, 2007); (ix) intellectual property rights (Zerbe, 2005; Lor \& Britz, 2005; Myburgh, 2011; Asongu, 2013b, 2015a; Andrés \& 
Asongu, 2013ab; Andrés et al., 2014); (x) spatiality in knowledge production (Bidwell et al., 2011; Neimark, 2012); (xi) KE in the transformation of space (Moodley, 2003; Maswera et al., 2008); (xii) KE related to finance (Asongu, 2013c, 2014b, 2015b) and (xiii) KE convergence or catch-up in light of the development miracle from East Asia (Kim et al., 2012; Bezmen \& Depken, 2004; Andrés et al., 2014; Andrés \& Asongu, 2013ab; Asongu, 2015bc, 2013de).

There has also been an evolving literature on the effect of development assistance on development outcomes in the African continent. Some recent studies include: (i) GyimahBrempong and Racine (2014) and Kargbo and Sen (2014) on the positive impact of development assistance on economic growth and (ii) the potentially questionable economics of development assistance with notable works from Banuri (2013), Krause (2013), Ghosh (2013), Monni and Spaventa (2013), Wamboye et al. (2013), Titumir and Kamal (2013), Quartey and Afful-Mensah (2014) and Asongu (2014c, 2015de). Consistent with Amin (2014), foreign aid to developing countries could be principally motivated by neo-colonialism. Quartey and Afful-Mensah (2014) have established that there is need for African countries to reconsider their overly reliance on foreign aid by assessing alternative sources of finance. The stances of Afful-Mensah, Amin and Quartey are in line with: (i) Ndlovu-Gatsheni (2013) on the entrapment of Africa into neocolonial 'foreign aid influential webs' and (ii) Kindiki (2011) on the imperative for Africa to limit its overly dependence on foreign aid. Obeng-Odoom (2013) has recommended that foreign aid oriented policies should be based essentially on the fundamental needs of citizens in recipient nations. The position of Obeng-Odoom is shared by Arthur and Quartey (2008) who have expressed the need for a more holistic approach to foreign aid location decisions: an approach that takes into account all stakeholders in international policies for migration management.

Noticeable in the above literature and to the best of our knowledge, very few studies have assessed the relevance of foreign aid in KE in developing countries. As far as we have reviewed, studies closest to this line of inquiry are: Asiedu and Nandwa (2007); Preece (2013) and Asiedu (2014). Asiedu and Nandwa (2007) have investigated if development assistance in education affects economic growth by disaggregating data into: (i) primary, secondary and tertiary education and (ii) low and middle income countries. The study finds that the impact of foreign aid varies (in sign and magnitude) depending on the type of aid and income category. Preece (2013) has engaged the nexus between the international agenda for lifelong learning and financial aid to low income nations (especially those from Africa) to show that international aid priorities 
negatively affect government policies and choices for lifelong learning in recipient countries. Asiedu (2014) has examined if foreign aid in education significantly influences growth in SubSaharan Africa to conclude that, aid in education (especially primary schooling) broadly has a positive effect on growth.

In light of the above, this study contributes to the $\mathrm{KE}$ and foreign aid literature by investigating the effect of foreign aid on education and lifelong learning in 53 African countries for the period 1996-2010. Lifelong learning is measured as the combined knowledge acquired during the primary, secondary and tertiary levels of education. Foreign aid dynamics include: Total aid, aid from Multilateral Donors (MD) and aid from the Development Assistance Committee (DAC) countries. The empirical evidence is based on an endogeneity-robust Generalized Method of Moments.

We also contribute to the existing literature by introducing a measure of lifelong learning in African countries. This is essentially because, despite textual African related foreign aid and lifelong learning literature (Preece, 2013), a measure of lifelong learning with which to extend the underlying literature is missing. After exploring a substantial bulk of literature on education and lifelong learning, Tuijnman (2003) has concluded that an all-inclusive lifelong learning indicator could only be comprehensively derived in the distant future: "But given the current state of play of the social sciences, and in particular of survey practice and indicator measurement, the time when a holistic and comprehensive framework of lifelong learning indicators can be proposed lies far in the future" (p.471). Moreover, "To date only two macro level studies, i.e. the European Lifelong Learning Indicators (ELLI) instrument developed by the EU (2010) and the Composite Learning Index (CLI) instrument developed by the Canadian Council on Learning (undated.), have dealt with this issue" (Luo, 2015, p.19). While the ELLI is exclusively focused on European countries, the CLI is Canada's indicator for progress in lifelong learning. Consistent with Asongu and Nwachukwu (2015a), these two indicators consists of dimensions of 'learning to be', 'learning to live together', 'learning to do' and 'learning to know'. There are two principal drawbacks in the application of these indicators to African countries: (i) they are exclusively focused on Canada and European countries and (ii) to the best of our knowledge, only data on the dimension of 'learning to know' is available for African countries. Hence, lifelong learning within the framework of this study is defined as the combined knowledge acquired during primary, secondary and tertiary educational levels. 
The interest of examining the effect of foreign aid on education and lifelong learning is at least fourfold, notably: (i) the critical role of lifelong learning in Africa when the continent is lagging in terms of knowledge economy (KE) which is essential for $21^{\text {st }}$ century economic prosperity; (ii) contributing to the growing debates on the effects of foreign aid; (iii) extending a new stream of learning literature and (iv) engaging a new paradigm on 'soft economics' which has been built on foreign aid misallocation and growing poverty levels in Africa. First, the relevance of lifelong learning in African $\mathrm{KE}$ is crucial because, there is some growing disturbing evidence that the knowledge index of the continent has dropped during the period 2000 to 2009 and remains substantially below those of other regions in the world (Anyanwu, 2002). This has led to a growing stream of studies on KE that are essentially motivated by the need for more KE on the continent (Tchamyou, 2015; Asongu, 2015c). $\quad$ Second, complementary to the foreign aid literature engaged above, international aid policies are distorting lifelong learning policies in African countries (Preece, 2013). Third, the paper extends an interesting strand of studies on achieving development success based on learning from different activities (Nyarko, 2013) or success strategies (Lee, 2009; Lee \& Kim, 2009; Wa Gĩthĩnji \& Adesida, 2011; Babatunde, 2012; Fosu, 2013).

Fourth, we engage a new paradigm on 'soft economics' which has been built on foreign aid misallocation and growing poverty levels in Africa. Accordingly, the April 2015 World Bank report on Millennium Development Goals has revealed that extreme poverty has been decreasing in all regions of the world with the exception of Africa (World Bank, 2015; Caulderwood, 2015), in spite of over two decades of growth resurgence that began in the mid 1990s (Fosu, 2015a, p.44). The concern about exclusive growth in Africa has motivated a recent book by Kuada (2015) which proposes a new paradigm of 'soft economics' as means to understanding African development trends ${ }^{1}$. Kuada (2015) has postulated that the introduction of human capability development and emphasis on 'soft economics' as opposed to 'strong economics' (or structural adjustment policies) are crucial in assessing and understanding recent trends in African development that have been characterized by exclusive growth, high unemployment and increasing poverty levels. The narrative of Kuada (2015) on 'soft economics' for inclusive growth, poverty alleviation and employment in Africa is consistent with a recent stream of

\footnotetext{
${ }^{1}$ The issue of exclusive growth is also the focus of a recent book by Fosu (2015bc) which is devoted to elucidating: (i) the role of institutions in the underlying growth resurgence and (ii) myths behind Africa's recent growth resurgence.
} 
African development literature that has focused on the imperative to tailor development assistance towards alternative mechanisms in order to ultimately boost employment, improve human resources and reduce poverty (Simpasa et al., 2015; Page \& Shimeles, 2015; Jones et al., 2015; Asongu, 2015f; Jones \& Tarp, 2015; Page \& Söderbom, 2015).

In light of the above, four problems boldly standout, notably: (i) Africa's lagging position in knowledge acquisition in spite of the growing relevance of $\mathrm{KE}$ in $21^{\text {st }}$ century development; (ii) the conclusions of Preece (2013) that need to be empirically verified; (iii) the need to extend a growing stream of literature on using foreign aid for soft economics in view of improving human resources that are essential for poverty reduction and increasing employment and (iv) the absence of an indicator of lifelong learning for developing countries. Hence, the objective of this inquiry is to assess the effect of foreign aid on education and lifelong learning in Africa. Three main issues are assessed, notably: (i) the effect of aid on education; (ii) the incremental impact of aid on education and (iii) the effect of aid on lifelong learning. The rest of the study is organized as follows. Section 2 discusses the data and the methodology. The empirical results are covered in Section 3. Section 4 concludes.

\section{Design and Methods}

\subsection{Design}

We investigate a panel of 53 African countries with data of annual periodicity from African Development Indicators of the World Bank for the period 1996-2010. The interest of the sampled periodicity is to obtain results that are more relevant for fresh policy implications. The scope of Africa is in accordance with Preece (2013) which is partially motivating this line of inquiry. We measure the dependent variable of lifelong learning as the first principal component of primary, secondary and tertiary school educations. This dependent variable of interest is complemented with its constituent components to fully assess the difference between the effects on distinct components of lifelong learning and lifelong learning. The corresponding principal component analysis is discussed in Section 2.1 below.

Net official development assistance (NODA) is employed as the independent variable of interest. To add subtlety to the analysis, in a bid for robustness, NODA from Multilateral Donors (MD) and NODA from the Development Assistance Committee (DAC) countries are also used independently of the baseline Total NODA. Hence, we do not expect these aid variables to have 
different effects (in terms of significance and signs of estimates) on education and lifelong learning. However, we expect changes in the magnitude of significance on the dependent variables. Consistent with Andrés et al. (2014) in the KE literature, we control for trade openness, inflation, government expenditure and economic prosperity. We expect government expenditure, GDP growth and trade openness to positively affect lifelong learning, whereas inflation should have the opposite effect. Accordingly, government expenditure could promote lifelong learning if it is not captured by mismanagement and corruption. Economic prosperity and trade openness from intuition should be favorable to learning (Asongu, 2014c). Inflation could reduce expectations in the return on education and hence, reduce investment in long-term education. Definition of the variables, the summary statistics and correlation matrix are detailed in the Appendices. The summary statistics informs us that variables are comparable and display quite some significant variations such that we can be comfortable that reasonable estimation nexuses would emerge. The correlation matrix essentially serves to control for concerns of overparameterization and multicollinearity.

\subsection{Methods}

\subsubsection{Principal component analysis}

The concept of lifelong learning is multidimensional and complex to calibrate, essentially because it involves a learning process from birth to death. Moreover, to the best of our knowledge there is yet no universally acceptable indicator for the measurement of the phenomenon (Kirby et al., 2010). In this study, we define lifelong learning as the formal educational process entailing primary, secondary and tertiary schoolings. Hence, the phenomenon could also be appreciated as the combined knowledge gained in the course of these three levels of formal education (Asongu, 2015g; Tchamyou, 2015).

In light of the above, we use principal component analysis (PCA) to measure this combined knowledge gained. PCA is a common statistical technique that is employed to reduce a large set of highly correlated variables into a smaller set of variables that are uncorrelated but represent significant information in the constituent indictors. The Kaiser (1974) and Jolliffe (2002) criteria are used to retain the principal information contained in the three educational components. The criteria require that only principal components with an eigenvalue greater than the mean (or one) should be retained. As shown in Table 1 below, the first principal component 
(PC) has an eigenvalue of 1.955 and represents more than $65 \%$ of information in the combined educational constituents.

Table 1: Principal Component Analysis for educational index (Educatex)

\begin{tabular}{lccccccc} 
& \multicolumn{3}{c}{ Component Loadings } & & \multicolumn{2}{c}{ Cumulative } \\
\cline { 2 - 4 } & PSE & SSE & TSE & Proportion & Proportion & Eigen value \\
First PC & 0.443 & 0.659 & 0.607 & & 0.651 & 0.651 & 1.955 \\
Second PC & 0.868 & -0.147 & -0.474 & & 0.267 & 0.918 & 0.801 \\
Third PC & -0.223 & 0.737 & -0.638 & & 0.081 & 1.000 & 0.243 \\
\hline
\end{tabular}

PC: Principal Component. PSE: Primary School Enrolment. SSE: Secondary School Enrolment. TSE: Tertiary School Enrolment.

The index created via PCA is called Educatex, which is the measurement of lifelong learning. This indicator has been recently used by Asongu and Nwachukwu (2015a), Asongu and Nwachukwu (2016) in assessing the relationship between lifelong learning and governance. Consistent with the discussion in the introduction, Educatex is different from the two discussed lifelong learning macroeconomic indicators in at least two ways, notably, it focuses on: (i) developing countries and (ii) exclusively on the 'learning to know' dimension of the CLI and ELLI for Canada and European countries respectively.

We briefly devote some space to engaging the statistical relevance of the PC-derived lifelong learning measurement. In accordance with Asongu and Nwachukwu (2015ab, 2016), we engage the justification of PC-augmented indicators at two levels, namely: general and specific points. From a general perspective, Pagan (1984, p. 242) has provided an interesting analysis on concerns arising from regressors that are the outcome of some initial estimations. The issues raised are allied to the efficiency, validity and consistency of estimated parameters. According to the account, whereas two-step estimators are for the most part reliable, they provide only few valid inferences. These issues have been confirmed in contemporary studies, notably: Oxley and McAleer (1993), Ba and Ng (2006), McKenzie and McAleer (1997), and Westerlund and Urbain (2013a).

With respect to the specific point, we are using Educatex which is a PC-derived indicator. Concerns about PC indicators have been substantially engaged by Westerlund and Urbain (2012, 2013b) who have built on previous works (mentioned in the previous paragraph) and other related studies (Stock and Watson, 2002; Pesaran, 2006; Bai, 2009; Bai, 2003; GreenawayMcGrevy et al., 2012). These authors have advised that normal corollaries are possible with PCfactor loadings if corresponding estimated coefficients converge towards their true values at the rate of $\sqrt{N T}$ (where $\mathrm{N}$ represents cross-section observations and $\mathrm{T}$ denotes the number of time 
series). In addition, Westerlund and Urbain (2012, 2013b) have argued that the underlying conditions for convergence (essential for good inferences of estimated parameters derived from PC factor loadings) are more feasible for a comparatively large sample. However, there is no mention of how large should be large. With respect to our sample, we are unable to increase N, because 53 of the 54 countries in the African continent have been sampled, with the exception of South Sudan for which data is not available before 2011. As concerns T, for which we have a starting year of 1996, Asongu and Nwachukwu (2015ab, 2006) have employed the PCaugmented factors using the same periodicity adopted by this line of inquiry.

\subsubsection{Estimation technique}

There is a threefold justification for the employment of a dynamic System Generalized Method of Moments (GMM) as an estimation strategy. First, it enables the control of endogeneity in the regressors because all are instrumented. Second, the potential small sample biases issues of the difference estimator are mitigated. Third, cross-country variations are not eliminated. Therefore, consistent with Bond et al. (2001), the System GMM procedure (Arellano \& Bover, 1995; Blundell \& Bond, 1998) has been chosen relative to the Difference estimator (Arellano \& Bond, 1991). In the specification exercise, a two-step approach is preferred to the one-step method because it is accounts for heteroscedasticity. Moreover, we control for time fixed effects. In order to investigate the validity of the models, two tests are performed: the Arellano and Bond $(\mathrm{AR}(2))$ test for the absence of autocorrelation in the residuals and the Sargan overidentifying restrictions (OIR) test for the validity of the instruments. Due to the concern of instrument proliferation, we have used three-year non-overlapping intervals (NOI). The three-year NOI are also essential for mitigating short-term (or business cycle disturbances). Above all, it ensures that the basic condition for the use of a GMM estimation procedure as estimation strategy: $N>T$ $(53>5)$.

In light of the above, the GMM equations in level and first difference are as follows:

$$
\begin{aligned}
& E d u_{i, t}=\sigma_{0}+\sigma_{1} E d u_{i, t-1}+\sigma_{2} T_{i, t}+\sigma_{3} M D_{i, t}+\sigma_{4} D A C_{i, t}+\sum_{j=1}^{4} \partial_{j} X_{i, t}+\eta_{i}+\xi_{t}+\varepsilon_{i, t} \\
& E d u_{i, t}-E d u_{i, t-1}=\sigma_{1}\left(E d u_{i, t-1}-E d u_{i, t-2}\right)+\sigma_{2}\left(T_{i, t}-T_{i, t-1}\right)+\sigma_{3}\left(M D_{i, t}-M D_{i, t-1}\right)+\sigma_{4}\left(D A C_{i, t}-D A C_{i, t-1}\right) \\
& +\sum_{j=1}^{4} \partial_{j}\left(X_{i, t}-X_{i, t-1}\right)+\left(\xi_{t}-\xi_{t-1}\right)+\left(\varepsilon_{i, t}-\varepsilon_{i, t-1}\right)
\end{aligned}
$$


Where: 't' represents the period and 'i' stands for a country. $E d u$ entails PSE, Primary School Enrolment; SSE, Secondary School Enrolment; TSE, Tertiary School Enrolment; Educatex, lifelong learning; $T$ is total aid; $M D$ is aid from multilateral donors; $D A C$ is aid from DAC countries; $X$ is the set of control variables (Government expenditure, GDP growth, trade openness and inflation); $\boldsymbol{\eta}_{i}$ is a country-specific effect; $\xi_{t}$ is a time-specific constant and $\varepsilon_{i, t}$ is an error term. The estimation procedure consists of simultaneously estimating the regression in levels (Eq. [1]) with that in first-difference (Eq. [2]), thereby exploiting all the orthogonality or parallel conditions between the lagged endogenous variable and error term.

We devote more space to articulating how potentially exogenous covariates are handled by the estimated technique. For example government expenditure may be viewed as being treated as exogenous, in spite of knowledge that a key issue in foreign aid is the substitution between government expenditure and foreign aid. The potentially endogenous nature of government expenditure is addressed by specificities of the estimation technique, since lagged levels of government expenditure are used as instruments in the difference equation and lagged differences of government expenditure used as instruments in the level equation. This contributes to the exploitation of all orthogonality conditions between the lagged dependent variable and errors terms in order to ultimately address the concern of endogeneity.

\section{Empirical results}

This section assesses three main issues, notably, the: notably: (i) the effect of aid on education; (ii) the incremental impact of aid on education and (iii) the effect of aid on lifelong learning. To address these issues, we investigate the impacts of foreign aid on the three educational variables and one lifelong learning indicator. In this light, comparing the impact of the first-three schooling indicators is essential to fully appreciate the effect on the lifelong learning indicator. While Table 2 represents the main assessment with Total NODA, Table 3 has been employed for sensitivity analysis in order to further investigate the effects of NODA from the Development Assistance Committee (Panel A) and Multilateral Donors (Panel B). Irrespective of tables, but for a few exceptions, the models are overwhelmingly valid based on the 
information criteria highlighted in the preceding section. Accordingly, for the most part, the null hypotheses of the Sargan OIR and AR(2) tests are not rejected ${ }^{2}$.

Based on the evidence in Table 2 below, the following are established. First, total aid increases only primary schooling and lifelong learning, with the magnitude of the former significantly higher. Second, effects on secondary and tertiary school enrolments are not significant. Third, although some of the control variables are insignificant, they nonetheless overwhelmingly have the expected signs.

\section{Table 2: The effect of foreign aid on lifelong learning}

\begin{tabular}{|c|c|c|c|c|c|c|c|c|}
\hline \multirow[b]{3}{*}{ Education (-1) } & \multicolumn{8}{|c|}{ Dependent variable: Education } \\
\hline & \multicolumn{2}{|c|}{ Primary Schooling } & \multicolumn{2}{|c|}{ Secondary Schooling } & \multicolumn{2}{|c|}{ Tertiary Schooling } & \multicolumn{2}{|c|}{ Lifelong Schooling (Educatex) } \\
\hline & $\begin{array}{l}0.925 * * * \\
(0.000)\end{array}$ & $\begin{array}{l}1.227 * * * \\
(0.000)\end{array}$ & $\begin{array}{l}0.923 * * * \\
(0.000)\end{array}$ & $\begin{array}{l}1.047 * * * \\
(0.000)\end{array}$ & $\begin{array}{l}1.230 * * * \\
(0.000)\end{array}$ & $\begin{array}{l}1.153 * * * \\
(0.000)\end{array}$ & $\begin{array}{l}1.105 * * * \\
(0.000)\end{array}$ & $\begin{array}{l}1.139 * * * \\
(0.000)\end{array}$ \\
\hline Constant & $\begin{array}{l}8.413 \\
(0.699)\end{array}$ & $\begin{array}{l}-17.746 \\
(0.153)\end{array}$ & $\begin{array}{l}5.028 \\
(0.122)\end{array}$ & $\begin{array}{l}1.510 \\
(0.484)\end{array}$ & $\begin{array}{l}-0.633 \\
(0.231)\end{array}$ & $\begin{array}{l}-0.876 \\
(0.402)\end{array}$ & $\begin{array}{l}0.191 * * \\
(0.026)\end{array}$ & $\begin{array}{l}0.199 \\
(0.130)\end{array}$ \\
\hline NODA (Total) & $\begin{array}{l}0.289 \\
(0.255)\end{array}$ & $\begin{array}{l}\mathbf{0 . 7 8 1} * * * \\
(0.000)\end{array}$ & $\begin{array}{l}-0.098 \\
(0.281)\end{array}$ & $\begin{array}{l}0.119 \\
(0.300)\end{array}$ & $\begin{array}{l}0.024 \\
(0.317)\end{array}$ & $\begin{array}{l}0.058 \\
(0.445)\end{array}$ & $\begin{array}{l}0.008 * \\
(0.087)\end{array}$ & $\begin{array}{l}0.014 * \\
(0.098)\end{array}$ \\
\hline Gov. Expenditure & --- & $\begin{array}{l}0.092 \\
(0.408)\end{array}$ & --- & $\begin{array}{l}-0.008 \\
(0.918)\end{array}$ & --- & $\begin{array}{l}0.057 \\
(0.113)\end{array}$ & --- & $\begin{array}{l}0.006 \\
(0.268)\end{array}$ \\
\hline GDP growth & --- & $\begin{array}{l}0.360 \\
(0.193)\end{array}$ & --- & $\begin{array}{l}0.180 \\
(0.505)\end{array}$ & --- & $\begin{array}{l}-0.021 \\
(0.587)\end{array}$ & --- & $\begin{array}{l}0.005 \\
(0.291)\end{array}$ \\
\hline Trade & --- & $\begin{array}{l}-0.045 \\
(0.315)\end{array}$ & --- & $\begin{array}{l}-0.022 \\
(0.105)\end{array}$ & --- & $\begin{array}{l}0.006 \\
(0.514)\end{array}$ & --- & $\begin{array}{l}-0.001 * * \\
(0.036)\end{array}$ \\
\hline Inflation & --- & $\begin{array}{l}-0.076 \\
(0.819)\end{array}$ & --- & $\begin{array}{l}-0.156 \\
(0.428)\end{array}$ & --- & $\begin{array}{l}-0.067 \\
(0.223)\end{array}$ & --- & $\begin{array}{l}-0.001 \\
(0.853)\end{array}$ \\
\hline $\begin{array}{l}\text { Time effects } \\
\operatorname{AR}(2)\end{array}$ & $\begin{array}{l}\text { Yes } \\
(\mathbf{0 . 1 5 2 )}\end{array}$ & $\begin{array}{l}\text { Yes } \\
(\mathbf{0 . 1 5 8 )}\end{array}$ & $\begin{array}{l}\text { Yes } \\
(\mathbf{0 . 2 8 4 )}\end{array}$ & $\begin{array}{l}\text { Yes } \\
(\mathbf{0 . 8 4 6 )}\end{array}$ & $\begin{array}{l}\text { Yes } \\
(\mathbf{0 . 8 1 3 )}\end{array}$ & $\begin{array}{l}\text { Yes } \\
(\mathbf{0 . 5 9 7 )}\end{array}$ & $\begin{array}{l}\text { Yes } \\
(\mathbf{0 . 1 8 0 )}\end{array}$ & $\begin{array}{l}\text { Yes } \\
\mathbf{( 0 . 1 3 1 )}\end{array}$ \\
\hline Sargan OIR & $(0.036)$ & $(0.134)$ & $(0.290)$ & $(0.089)$ & $(0.422)$ & $(0.329)$ & $(0.795)$ & $(0.638)$ \\
\hline Wald (joint) & $\begin{array}{l}24.671 * * * \\
(0.000)\end{array}$ & $\begin{array}{l}100.43 * * * \\
(0.000)\end{array}$ & $\begin{array}{l}1604.5^{* * * *} \\
(0.000)\end{array}$ & $\begin{array}{l}\text { 3761**** } \\
(\mathbf{0 . 0 0 0 )}\end{array}$ & $\begin{array}{l}\mathbf{5 9 4 . 8 5 * * * *} \\
(0.000)\end{array}$ & $\begin{array}{l}385.57 * * * \\
(\mathbf{0 . 0 0 0 )}\end{array}$ & $\begin{array}{l}269.73 * * * \\
(0.000)\end{array}$ & $\begin{array}{l}402.35 * * * * \\
(0.000)\end{array}$ \\
\hline Instruments & 14 & 18 & 14 & 18 & 14 & 18 & 14 & 18 \\
\hline Countries & 64 & 33 & 40 & 28 & 33 & 25 & 29 & 22 \\
\hline Observations & 174 & 113 & 134 & 87 & 112 & 80 & 87 & 61 \\
\hline
\end{tabular}

\footnotetext{
${ }^{2}$ It is important to note that, in order to assess the validity of the models, two tests have been performed, notably: the Arellano and Bond autocorrelation test that examines the null hypothesis of no autocorrelation and the Sargantest which investigates the over-identification restrictions. The latter test examines whether instruments are not correlated with the error term in the main equation. The null hypothesis of this test is the position that the instruments as a group exhibit strict exogeneity or do not suffer from endogeneity. We have only reported $\operatorname{AR}(2)$ in difference because it is more relevant than the AR(1) which detects autocorrelation in levels. For the most part, we have neither rejected the Sargan null hypothesis for the validity of the instruments nor the AR(2) null for the absence of autocorrelation.
} 
In order to investigate the robustness of findings in Table 2, we engage some sensitivity analysis using alternative measures of NODA, namely: NODA from the Development Assistance Committee (DAC) countries and NODA from Multilateral Donors (MD). While Panel A of Table 3 shows results from NODADAC, the findings of NODAMD are provided in Panel B. The estimates of lifelong learning and its constituent components are broadly consistent with those of Table 2, with the exception of aid from MD which positively affects only lifelong learning because the Sargan OIR is significant in the 'primary school'- related regressions. The control variables also have the expected signs.

\section{Table 3: Sensitivity analysis with foreign aid from DAC countries and Multilateral Donors}

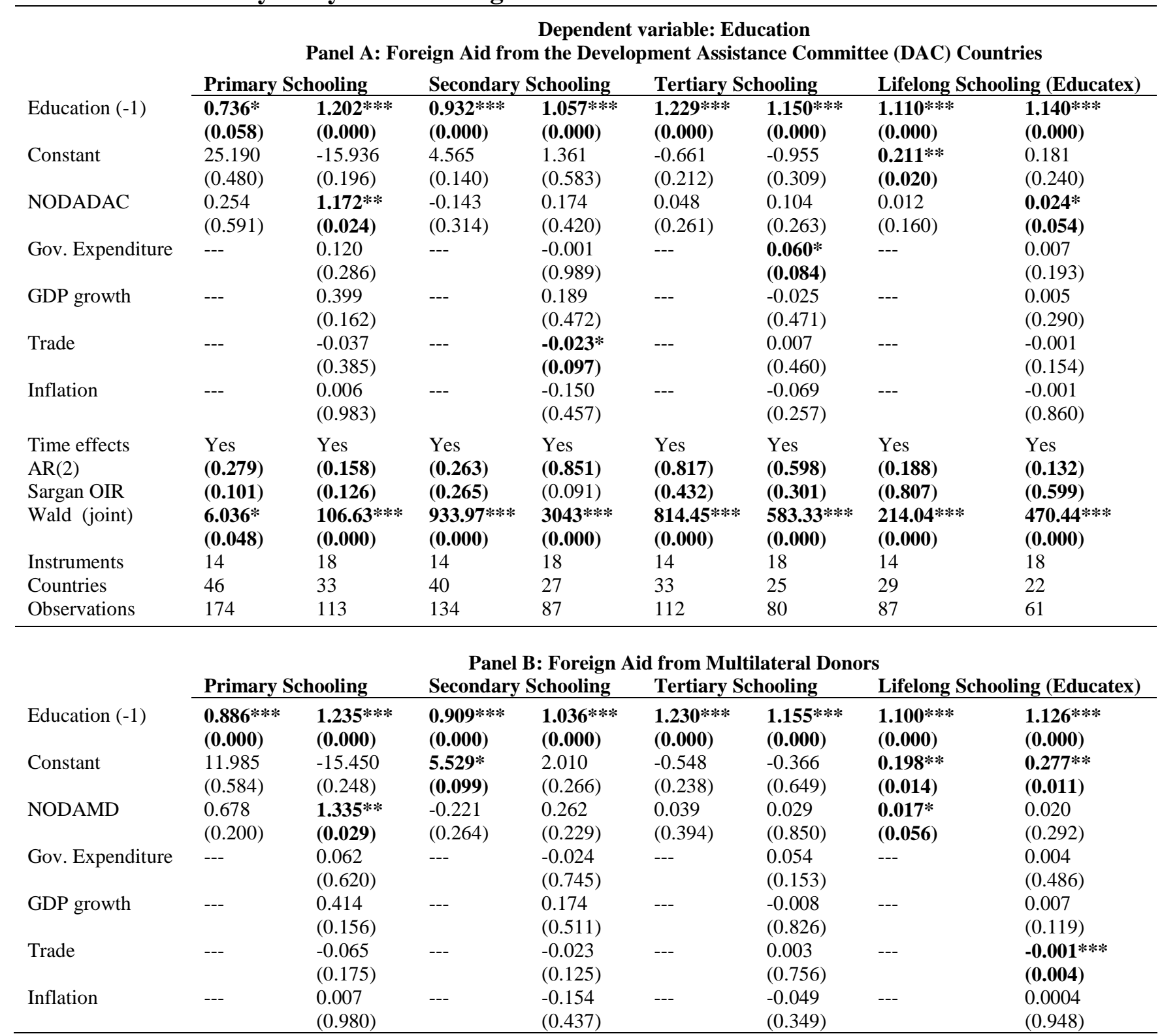




\begin{tabular}{lllllllll}
\hline Time effects & Yes & Yes & Yes & Yes & Yes & Yes & Yes & Yes \\
AR(2) & $\mathbf{( 0 . 1 5 8 )}$ & $\mathbf{( 0 . 1 3 3 )}$ & $\mathbf{( 0 . 2 9 0 )}$ & $\mathbf{( 0 . 8 4 8 )}$ & $\mathbf{( 0 . 8 1 4 )}$ & $\mathbf{( 0 . 6 0 3 )}$ & $\mathbf{( 0 . 1 7 8 )}$ & $\mathbf{( 0 . 1 4 2 )}$ \\
Sargan OIR & $(0.020)$ & $(0.072)$ & $\mathbf{( 0 . 3 3 6 )}$ & $\mathbf{( 0 . 0 8 7 )}$ & $\mathbf{( 0 . 4 1 5 )}$ & $\mathbf{( 0 . 3 8 5 )}$ & $\mathbf{( 0 . 7 6 5 )}$ & $\mathbf{( 0 . 6 4 3 )}$ \\
Wald (joint) & $\mathbf{1 7 . 3 1 1} * * *$ & $\mathbf{8 5 . 5 1 1} * * *$ & $\mathbf{1 9 1 1 . 8} * * *$ & $\mathbf{3 6 0 7} * * *$ & $\mathbf{4 3 0 . 6 6 * * *}$ & $\mathbf{2 8 3 . 6 6 * * *}$ & $\mathbf{3 1 0 . 9 6 * * *}$ & $\mathbf{3 2 3 . 5 4} * * *$ \\
& $(\mathbf{0 . 0 0 0 )}$ & $\mathbf{( 0 . 0 0 0 )}$ & $\mathbf{( 0 . 0 0 0 )}$ & $\mathbf{( 0 . 0 0 0 )}$ & $\mathbf{( 0 . 0 0 0 )}$ & $\mathbf{( 0 . 0 0 0 )}$ & $\mathbf{( 0 . 0 0 0 )}$ & $\mathbf{( 0 . 0 0 0 )}$ \\
Instruments & 14 & 18 & 14 & 18 & 14 & 18 & 14 & 18 \\
Countries & 46 & 33 & 40 & 28 & 33 & 25 & 27 & 22 \\
Observations & 174 & 113 & 134 & 87 & 112 & 80 & 87 & 61 \\
\hline
\end{tabular}

***, $* *$, and $*$ indicate significance at $1 \%, 5 \%$ and $10 \%$ levels respectively. AR(2): Second Order Autocorrelation test. OIR: Overidentifying Restrictions test. The significance of bold values is twofold. 1) The significance of estimated coefficients and the Wald statistics. 2) The failure to reject the null hypotheses of: a) no autocorrelation in the AR(2) tests and; b) the validity of the instruments in the Sargan OIR test. P-values in bracket. Gov: Government. NODADAC: Net Official Development Assistance from the Development Assistance Committee. NODAMD: Net Official Development Assistance from Multilateral Donors.

The overwhelmingly positive effect of primary education is consistent with Asiedu (2014) and could be partly elucidated by the fact that primary schooling entails higher social returns relative to other educational levels when economies are at initial stages of development. This elucidation is broadly in line with Petrakis and Stamatakis (2002) and Asiedu (2014). Moreover, it is interesting to note that the findings on lifelong learning do not validate the conclusions from Preece (2013) on the position that international aid priorities have negative effects on government policies and choices for lifelong learning.

In light of the paradigm on 'soft economics' from Kuada (2015) and associated studies ${ }^{3}$ engaged in the introduction, inclusive growth in Africa can be sustained by channeling foreign aid through mechanisms of education and lifelong learning. This inference is consistent with the recent evidence that foreign aid is positive to economic growth (Kargbo \& Sen, 2014; GyimahBrempong \& Racine, 2014) and the impact is more apparent when development assistance is channeled through educational mechanisms (Asiedu \& Nandwa, 2007; Asiedu, 2014).

As Fields (2015) has shown, labour market supply side (low skills) deficiencies that are strongly associated with the welfare of African countries can be addressed by channeling foreign aid effectively to the improvement of learning and acquisition of skills. Moreover, there is a longstanding issue of education being hampered in Africa by missing inputs like textbooks and other material (Filmer \& Pritchett, 1997). This is consistent with recent evidence of depleting knowledge infrastructure, brain-drain, outdated curricula and limited direct linkages between science and technology (Tchamyou, 2015; Asongu, 2015g). Moreover, the continent has been experiencing a downward trend in KE (Anyanwu, 2012). Kamara et al. (2007) have suggested that unless bold measures are put in place to reinvigorate technology and science, higher

\footnotetext{
${ }^{3}$ Please see: Simpasa et al. (2015), Page and Shimeles (2015), Jones et al. (2015), Asongu (2015f), Jones and Tarp (2015) and Page and Söderbom (2015).
} 
education and innovation, Africa may miss development opportunities and positive externalities associated with knowledge-based-economies. Based on our findings, foreign aid can be used to reinvigorate the elements suggested by Kamara et al. in at least three main dimensions.

First, development assistance can be used to increase the ratio of research and development (R\&D) on GDP. Education would consolidate the country's ability to acquire new knowledge and technology needed for the drive towards KE. Development assistance could also be tailored towards efforts of enhancing core human resource development as well as indigenous R\&D platforms that are essential for consolidating technological blocks and imparting knowledge in societies. Consistent with Tchamyou (2015), practical and disciplinary factors by citizens are important in achieving these educational strategies. Hence, as supported by Lee (2009), foreign aid would have to be tailored in conjunction with considerable improvements in the quality of institutions in recipients countries, including the autonomy and capacity of local governments implementing the 'foreign aid'-oriented schemes.

Second, given the constantly changing technological environments, in order for workers to adapt to changing conditions of technology, foreign aid should also be devoted towards enhancing vocational and technical trainings, as well as encouraging trainings at work places. This recommendation is based on the fact that as African countries develop, technological competence would be a critical component in the quality of its human resources, in tacit as well as specialized knowledge. Moreover, for these initiatives to work, when formulated, their implementation would require foreign assistance policies to favor the nurturing of high-caliber scientists and engineers that are capable of facing and handling challenges in the frontiers of science and technology. As suggested by Tchamyou (2015) and Asongu (2015h), it would be relevant to complement education and industrialization for KE. Hence foreign aid policies could be tailored towards encouraging sustainable development by ensuring that: (i) education results in industrialization and technological learning and (ii) industrialization increases the rate of investment in education which further increases the demand for education.

Third, on the linkage between education and innovation, foreign aid policies could be adjusted to facilitate reversed engineering because the know-how of academic institutions in Africa is currently more imitative and adaptive in nature (Asongu, 2014d, p. 579). This strategy which is consistent with Bezmen and Depken (2004) has very relevant practical implications because South Korea achieved its economic miracle by copying technology-intensive 
commodities from more advanced countries (Kim et al., 2012; Kim, 1997; Kim \& Kim, 2014). It follows that foreign aid policies could facilitate less stringent property rights needed for informal transfer of technology, reverse engineering and mastery of technology-intensive commodities by African countries because they are at the initial stage of industrialization. This narrative is consistent with recent African KE studies which have concluded that less stringent intellectual property rights (IPRs) could reduce poverty (Asongu, 2014e) and boost scientific publications (Asongu, 2014d) on the continent. It follows that the use of foreign aid to encourage lifelong learning strategies in recipient countries augurs well with the ultimate goal of increasing living standards and human development.

It is also important to noted that whereas the policy recommendations partly build on Kim et al. (2012) in arguing for foreign aid to favor less stringent property rights, the implications do not engage the debate over whether less or more stringent IPRs are needed. What we seek to articulate in the recommendations is that alternative forms of IPRs such as utility models (or patents) could promote education for adaptive and minor innovations. This implication is in accordance with Kim (1997, p. 220) in the perspective that, it is exceedingly difficult for countries in the Third World to become industrialized by tailoring academic policies towards developing technological innovations. In essence, since huge investments in R\&D are associated with the underlying scheme, the available R\&D budget would be more optimally used for adaptive innovations.

\section{Conclusion and future directions}

This study has investigated the effect of foreign aid on education and lifelong learning in 53 African countries for the period 1996-2010. Three main issues have been assessed, notably: (i) the effect of aid on education; (ii) the incremental impact of aid on education and (iii) the effect of aid on lifelong learning. Lifelong learning has been measured as the combined knowledge acquired during the primary, secondary and tertiary levels of education. The empirical evidence is based on an endogeneity-robust Generalized Method of Moments. The following findings have been established. First, the aid variables have positive effects on primary school enrolment and lifelong learning, with the exception of aid from MD which positively affects only lifelong learning. Second, the positive effect on primary school enrolment consistently has a higher magnitude compared to the impact on lifelong learning. Third, the effects of aid dynamics on 
secondary and tertiary school enrolments are not significant. We have also contributed to the literature by proposing a lifelong learning indicator for developing countries.

It is important to bear in mind that, the indicator of lifelong learning used in this study fails to capture ethical and moral conscientious learning that are linked with foreign aid. Furthermore, without a doubt, lifelong learning does not stop with schooling because practical realities of life are equally educative, especially in the first few years of work. Thus, the working environment also plays into how foreign aid potentially affects lifelong learning. Unfortunately, as we have justified in the introduction, we have limited the indicator of lifelong learning to schooling because of data availability constraints. Hence, future research could incorporate highlighted post-schooling factors in order to advance scholarship in the established relationships. In the same vein, other schooling indicators like standardized tests, dropout rates and repetition rates could also be considered. Future lines of inquiry devoted to improving the extant of knowledge on the established nexuses could focus on country-specific studies to enable more targeted policy implications. Furthermore, future research could also incorporate more dimensions of heterogeneity in foreign aid as emphasized by Asiedu and Nandwa (2007). Within this framework, focusing on different aid components or sectors (like education) is worthwhile. 


\section{Appendices}

\section{Appendix 1: Definitions of variables}

\begin{tabular}{lll} 
Variable(s) & Definition(s) & Source(s) \\
\hline Aid1: NODA (Total) & Total Net Official Development Assistance (\% of GDP) & World Bank (WDI) \\
Aid 2: NODADAC & Net Official Development Assistance for the & World Bank (WDI) \\
& Development Assistance Committee (\% of GDP) & \\
Aid 3: NODAMD & Net Official Development Assistance from Multilateral & World Bank (WDI) \\
& Donors (\% of GDP) & World Bank (WDI) \\
Primary Schooling (PS) & Primary School Enrolment (\% of Gross) & World Bank (WDI) \\
Secondary Schooling (SS) & Secondary School Enrolment (\% of Gross) & World Bank (WDI) \\
Tertiary Schooling (TS) & Tertiary School Enrolment (\% of Gross) & PCA \\
Educational index & First principal component of PS, SS \& TS & World Bank (WDI) \\
GDP growth & Gross Domestic Product growth rate (annual \%) & World Bank (WDI) \\
Trade Openness & Exports plus Imports of Commodities (\% of GDP) & World Bank (WDI) \\
Government Expenditure & Government Final Consumption Expenditure(\% of GDP) & World Bank (WDI) \\
Inflation & Consumer Price Index (annual \%) & .
\end{tabular}

WDI: World Bank Development Indicators. GDP: Gross Domestic Product. PCA: Principal Component Analysis. NODA: Net Official Development Assistance. NODADAC: NODA from the Development Assistance Committee (DAC) countries. NODAMD: NODA from Multilateral Donors.

\section{Appendix 2: Summary statistics}

Total Net Official Development Assistance NODA from DAC countries NODA from Multilateral Donors Primary School Enrolment Secondary School Enrolment Tertiary School Enrolment Educational index GDP growth

Trade Openness Government Expenditure Inflation

\begin{tabular}{ccccc} 
Mean & S.D & Min & Max & Obs. \\
\hline 10.889 & 12.029 & 0.015 & 102.97 & 253 \\
6.278 & 7.303 & -0.003 & 68.063 & 253 \\
4.525 & 5.083 & 0.004 & 33.249 & 253 \\
94.414 & 25.647 & 28.298 & 149.70 & 237 \\
38.683 & 26.489 & 5.372 & 115.03 & 199 \\
6.228 & 8.489 & 0.241 & 53.867 & 183 \\
-0.070 & 1.327 & -2.103 & 5.527 & 152 \\
4.755 & 5.587 & -11.272 & 49.367 & 254 \\
78.340 & 39.979 & 20.980 & 250.95 & 247 \\
4.495 & 8.064 & -17.387 & 49.275 & 164 \\
56.191 & 575.70 & -45.335 & 8603.3 & 230
\end{tabular}

S.D: Standard Deviation. Min: Minimum. Max: Maximum. Obs: Observations. NODA: Net Official Development Assistance. DAC: Development Assistance Committee.

\section{Appendix 3: Correlation Analysis}

\begin{tabular}{|c|c|c|c|c|c|c|c|c|c|c|c|}
\hline GDPg & Trade & Gov.E & Inflation & Aid1 & Aid2 & Aid3 & PSE & SSE & TSE & Educatex & \\
\hline \multirow[t]{11}{*}{1.000} & 0.179 & 0.254 & -0.132 & 0.114 & 0.109 & 0.111 & 0.095 & -0.078 & -0.036 & -0.006 & GDPg \\
\hline & 1.000 & -0.070 & 0.024 & -0.083 & -0.061 & -0.114 & 0.261 & 0.389 & 0.057 & 0.283 & Trade \\
\hline & & 1.000 & -0.243 & 0.078 & 0.077 & 0.060 & 0.019 & 0.013 & 0.092 & 0.087 & Gov.E \\
\hline & & & 1.000 & -0.023 & -0.011 & -0.035 & -0.064 & -0.100 & -0.081 & -0.106 & Inflation \\
\hline & & & & 1.000 & 0.975 & 0.946 & -0.055 & -0.488 & -0.454 & -0.456 & Aid1 \\
\hline & & & & & 1.000 & 0.854 & -0.064 & -0.449 & -0.440 & -0.452 & Aid2 \\
\hline & & & & & & 1.000 & -0.026 & -0.481 & -0.422 & -0.409 & Aid3 \\
\hline & & & & & & & 1.000 & 0.452 & 0.257 & -0.635 & PSE \\
\hline & & & & & & & & 1.000 & 0.725 & 0.919 & SSE \\
\hline & & & & & & & & & 1.000 & 0.843 & TSE \\
\hline & & & & & & & & & & 1.000 & Educatex \\
\hline
\end{tabular}

GDPg: GDP growth rate. Gov. E: Government Expenditure. Aid1: Total Net Official Development Assistance (NODA). Aid2: NODA from the DAC countries. Aid3: NODA from Multilateral Donors. PSE: Primary School Enrolment. SSE: Secondary School Enrolment. TSE: Tertiary School Enrolment. Educatex: educational index. 


\section{References}

Aker, J., \& Mbiti, I. (2010). Mobile Phones and Economic Development in Africa. Journal of Economic Perspectives, 24(3), 207-232.

Amavilah, V. H., (2009). "Knowledge of African countries: production and value of doctoral dissertations," Applied Economics, 41,(7-9), pp. 977-989.

Amin, S., (2014). “Aid for Development”, Springer Briefs on Pioneers in Science and Practice, 16 , pp. $125-137$.

Andrés, A. R., \& Asongu, S. A., (2013a). "Fighting software piracy: which governance tools matter in Africa?", Journal of Business Ethics, 118(3), pp. 667-682.

Andrés, A. R., \& Asongu, S. A., (2013b). "Global dynamic timelines for IPRs harmonization against software piracy”, Economics Bulletin, 33(1), pp. 874-880.

Andrés, A. R., Asongu, S. A., \& Amavilah, V. H. S., (2014). "The Impact of Formal Institutions on Knowledge Economy", Journal of the Knowledge Economy: Forthcoming. http://link.springer.com/article/10.1007\%2Fs13132-013-0174-3

Anyanwu, J. C., (2012). "Developing Knowledge for the Economic Advancement of Africa", International Journal of Academic Research in Economics and Management Sciences, 1(2), pp. 73-111.

Arellano, M., \& Bond, S. (1991) "Some tests of specification for panel data: Monte Carlo evidence and an application to employment equations" The Review of Economic Studies 58, 277297.

Arellano, M., \& Bover, O. (1995) "Another look at the instrumental variable estimation of errorcomponents models" Journal of Econometrics 68, 29-52.

Arthur, P., \& Quartey, P., (2008), "The Use of Aid to Manage Migration: the case of Ghana", Ghana Journal of Development Studies, 5(1), pp. 20-38.

Asiedu, E. (2014). "Does Foreign Aid in Education Promote Economic Growth? Evidence From Sub-Saharan Africa”, Journal of African Development, 16(1), pp. 37-59.

Asiedu, E., \& Nandwa, B., (2007), "On the Impact of Foreign Aid in Education on Growth: How relevant is heterogeneity of aid flows and heterogeneity of aid recipients?", Review of World Economics, 143(4), pp. 631-649.

Asongu, S. A., (2013a). "How has mobile phone penetration stimulated financial development in Africa?", Journal of African Business, 14(1), pp. 7-18. 
Asongu, S. A., (2013b). "Harmonizing IPRs on Software Piracy: Empirics of Trajectories in Africa", Journal of Business Ethics, 118(3), pp. 667-682.

Asongu, S. A., (2013c). “The 'Knowledge Economy'-finance nexus: how do IPRs matter in SSA and MENA countries?”, Economics Bulletin, 33(1), pp. 78-94.

Asongu, S. A., (2013d). "Modeling the future of knowledge economy: evidence from SSA and MENA countries", Economics Bulletin, 33(1), pp. 612-624.

Asongu, S. A., (2013e). "On the Obituary of Scientific Knowledge Monopoly", Economics Bulletin, 33(4), pp. 2718-2731.

Asongu, S. A., (2014a). "Mobile banking and mobile phone penetration: which is more pro-poor in Africa?", African Governance and Development Institute Working Paper.

Asongu, S. A., (2014b). "Knowledge economy and financial sector competition in African countries", African Development Review, 26(2), pp. 333-346.

Asongu, S. A., (2014c). "Development thresholds of foreign aid effectiveness in Africa", International Journal of Social Economics, 41(11), pp. 1131-1155.

Asongu, S. A., (2014d). "Software Piracy and Scientific Publications: Knowledge Economy Evidence from Africa”, African Development Review, 26(4), pp. 572-583.

Asongu, S. A., (2014e). "Software piracy, inequality and the poor: evidence from Africa", Journal of Economic Studies, 41(4), pp. 526-553.

Asongu, S. A., (2015a). "Fighting software piracy in Africa: how do legal origins and IPRs protection channels matter?", Journal of Knowledge Economy:

http://link.springer.com/article/10.1007/s13132-012-0137-0

Asongu, S. A., (2015b). "Financial Sector Competition and Knowledge Economy: Evidence from SSA and MENA Countries", Journal of the Knowledge Economy:

http://link.springer.com/article/10.1007/s13132-012-0141-4

Asongu, S. A., (2015c). "The Comparative Economics of Knowledge Economy in Africa: Policy Benchmarks, Syndromes and Implications", Journal of the Knowledge Economy: http://link.springer.com/article/10.1007/s13132-015-0273-4

Asongu, S. A., (2015d). "Institutional benchmarking of foreign aid effectiveness in Africa", International Journal of Social Economics, 42(6): pp.543-565.

Asongu, S. A., (2015e). "On taxation, political accountability and foreign aid: empirics to a celebrated literature”, South African Journal of Economics, 83(2), pp. 180-198. 
Asongu, S. A., (2015f), "Reinventing foreign aid for inclusive and sustainable development: Kuznets, Piketty and the great policy reversal", Journal of Economic Surveys: doi/10.1111/joes.12109.

Asongu, S. A., (2015g). "Knowledge Economy Gaps, Policy Syndromes and Catch-up Strategies: Fresh South Korean Lessons to Africa", Journal of the Knowledge Economy: http://link.springer.com/article/10.1007/s13132-015-0321-0

Asongu, S. A., (2015h). "The Comparative Economics of Knowledge Economy in Africa: Policy Benchmarks, Syndromes and Implications", Journal of the Knowledge Economy: http://link.springer.com/article/10.1007/s13132-015-0273-4

Asongu, S. A, and Nwachuku, J. C., (2015a). "The incremental effect of education on corruption: evidence of synergy from lifelong learning", Economics Bulletin: Forthcoming.

Asongu, S. A, and Nwachuku, J. C., (2015b). "Revolution Empirics: Predicting the Arab Spring", Empirical Economics: Forthcoming

Asongu, S. A, and Nwachuku, J. C., (2016). "The Role of Lifelong Learning in Political Stability and Non-violence: Evidence from Africa", Journal of Economic Studies: Forthcoming.

Aubert, J. E., (2005). "Knowledge economies: A global perspective", In A. Bonfour \& L. Edvinsson (Eds.), Intellectual capital for communities. Elsevier, Oxford.

$\mathrm{Ba}$, J., and Ng S (2006). "Confidence intervals for diffusion index forecasts and inference for factor-augmented regression”, Econometrica, 74(4), pp. 1133-1150.

Babatunde, M. A., (2012). "Africa's Growth and Development Strategies: A Critical Review", African Development, Africa Development, XXXVII, (4), pp. 141-178.

Bai, J., (2003). "Inferential theory for factor models of large dimensions". Econometrica, 71 (1),pp.135-173.

Bai, J., (2009). "Panel data models with interactive fixed effects". Econometrica, 77(4), pp. 12291279.

Banuri, T., (2013). "Sustainable Development is the New Economic Paradigm", Development, 56(2), pp. 208-217.

Bezmen, T. L., \& Depken, C. A., (2004). "The impact of software piracy on economic development", Working Paper. Francis Marion University.

Bidwell, N. J., Winschiers-Theophilus, H., Kapuire, G. K., \& Rehm, M., (2011). "Pushing personhood into place: Situating media in rural knowledge in Africa", International Journal of Human-Computer Studies, 69 (10), pp. 618-631. 
Blundell, R., \& Bond, S., (1998). "Initial conditions and moment restrictions in dynamic panel data models", Journal of Econometrics, 87(1), pp.115-143.

Bond, S., Hoeffler, A., \& Tample, J., (2001). "GMM Estimation of Empirical Growth Models", University of Oxford.

Britz, J. J., Lor, P. J., Coetzee, I. E. M., \& Bester, B. C., (2006). “Africa as a knowledge society: A reality check", The International Information \& Library Review, 38, pp. 25-40.

Butcher, N., (2011). ICT in Africa. A Few Key Challenges, in: ICT, Education, Development, and the Knowledge Society, Thematic Paper prepared for GeSCI African Leadership in ICT Program, December 2011, pp. 33-39.

Carisle, S., Kunc, M., Jones, E., \& Tiffin, S., (2013). "Supporting innovation for tourism development through multi-stakeholder approaches: Experiences from Africa", Tourism Management, 35, pp. 59-69.

Caulderwood, K., (2015) "Sub-Saharan Africa Falls Behind In Fight Against Extreme Poverty:

World Bank Report”, International Business Times (April 14th 2015).

http://www.ibtimes.com/sub-saharan-africa-falls-behind-fight-against-extreme-

povertyworldbank-report-1881460 (Accessed: 19/04/2015)

Chandra, D. S., \& Yokoyama, K., (2011). "The role of good governance in the knowledge- based economic growth of East Asia - A study on Japan, Newly Industrialized Economies, Malaysia and China", Graduate School of Economics, Kyushu University.

Chavula, H. K., (2010). "The Role of Knowledge in Economic Growth. The African Perspective", ICT, Science and Technology Division (ISTD), United Nations Economic Commission for Africa (UNECA).

Cogburn, D., (2003). "Governing global information and communications policy: Emergent regime formation and the impact on Africa", Telecommunications Policy, 27, pp. 135-153.

Dahlman, C., Westphal, L. E., \& Kim, L., (1985). "Reflections on Korea's Acquisition of Technological Capability". In N. Rosenberg and C. Frisctak (eds), International Technology Transfer: Concepts, Measures and Comparisons. New York: Pagamon.

Demombynes, G., \& Thegeya, A. (2012, March). Kenya's Mobile Revolution and the Promise of Mobile Savings. World Bank Policy Research Working Paper, No. 5988.

European Union (EU). (2010). "The European Lifelong Learning Index (ELLI): Measuring lifelong learning across Europe". http://www.elli.org.

Fields, G., (2015). "Aid, Growth and Jobs", African Development Review, Supplement: Special Issue on "Aid and Employment", 27, ( S1), pp. 5-16. 
Filmer, D., \& Pritchett, L., (1997), "What Educational Production Functions Really Show : A Positive Theory of Education Spending”, World Bank Policy Research Paper No. 1795.

Ford, D. M., (2007). “Technologizing Africa: On the bumpy information highway", Computers and Composition, 24, pp. 302-316.

Fosu, A., (2013), “Achieving development success: Strategies and lessons from the developing world", UNU-WIDER Policy Brief (November).

Fosu, A. K., (2015a). "Growth, Inequality and Poverty in Sub-Saharan Africa: Recent Progress in a Global Context”, Oxford Development Studies, 43(1), pp. 44-59.

Fosu, A. K. (2015b). Growth and Institutions in African Development, First edited by Augustin K. Fosu, , Routledge Studies in Development Economics: New York.

Fosu, A. K. (2015c). Growth and institutions in African Development, in Growth and Institutions in African Development, First edited by Augustin K. Fosu, 2015, Chapter 1, pp. 1-17, Routledge Studies in Development Economics: New York.

Ghosh, J., (2013). "Towards a Policy Framework for Reducing Inequalities", Development, 56(2), pp. 218-222.

German, L., \& Stroud, A., (2007). "A Framework for the integration of diverse learning approaches: Operationalizing agricultural research and development (R\&D) linkages in Eastern Africa", World Development, 35(5), pp. 792-814.

Greenaway-McGrevy, R., Han, C., and Sul, D., (2012). "Asymptotic distribution of factor augmented estimators for panel regression”. Journal of Econometrics, 169 (1), pp. 48-53.

Gyimah-Brempong, K., \& Racine, J. S. (2014). “Aid and Economic Growth: A Robust Approach”, Journal of African Development, 16(1), pp. 1-35.

Jolliffe, I. T., (2002). Principal Component Analysis (2ndEd.), New York: Springer.

Jonathan, D., \& Camilo, T. (2008). Mobile banking and economic development: Linking adoption, impact and use. Asian Journal of Communication, 18(4), 318-322.

Jones, S., Page, J., Shimeles, A., \& Tarp, F., (2015). "Aid, Growth and Employment in Africa", African Development Review, Supplement: Special Issue on "Aid and Employment", 27,( S1), pp. $1-4$.

Jones, S., \& Tarp, F., (2015). "Priorities for Boosting Employment in Sub-Saharan Africa: Evidence for Mozambique", African Development Review, Supplement: Special Issue on "Aid and Employment", 27,( S1), pp. 56-70.

Kaiser, H. F., (1974). “An index of factorial simplicity”. Psychometrika, 39, pp. 31-36. 
Kamara, A. B., Bourish, L., \& Nyende, M., (2007). "Growing a Knowledge-Based Economy: Evidence from Public Expenditure on Education in Africa", Economic Research Working Paper No. 88.

Kargbo, P. M., \& Sen, K., (2014). "Aid Categories that Foster Pro-Poor Growth: The Case of Sierra Leone", African Development Review, 26(2), pp. 416-429.

Kim, E. M., (1997). Big Business, Strong State: Collusion and Conflict in South Korean Development, 1960-1990. State University of New York Press: New York.

Kim, E. M., and Kim, P. H., (2014). The South Korean Development Experience: Beyond Aid. Critical Studies of the Asia Pacific, Palgrave Macmillan.

Kim, Y., Lee, K., Park, W. G., \& Choo, K., (2012). “Appropriate intellectual property protection and economic growth in countries at different levels of development", Research Policy, 41(2), pp. 358-375.

Kindiki, M. M., (2011). "International Regime Governance and Apparel Labour Upgrading in Export Processing Zones in Urban Kenya”, African Review of Economics and Finance, 3(1), pp. 26-40.

Krause, U., (2013). "Innovation: The new Big Push or the Post-Development alternative?", Development, 56(2), pp. 223-226.

Kirby, J. R., Knapper, C., \& Lamon, P., (2010). "Development of a scale to measure lifelong learning", International Journal of Lifelong Education, 29(3), pp. 291-302.

Kuada, J., (2015). Private Enterprise-Led Economic Development in Sub-Saharan Africa The Human Side of Growth First edition by Kuada, J, Palgrave Macmillan: New York.

Lee, K., (2009), "How Can Korea be a Role Model for Catch-up Development? A 'Capabilitybased' View”, UN-WIDER Research Paper No. 2009/34.

Lee, K., \& Kim, B. Y., (2009), "Both Institutions and Policies Matter but Differently for Different Income Groups of Countries: Determinants of Long-Run Economic Growth Revisited", World Development, 37(3), 533-549.

Letiche, J. M., (2006). "Positive economic incentives. New behavioural economics and successful economic transitions", Journal of Asian Economics, 17, pp. 775-796.

Lin, B., (2006). "A sustainable perspective on the knowledge economy: A critique of Austrian and mainstream view", Ecological Economics, 60(1), pp. 324-332.

Lor, P. J., \& Britz, J., (2005). "Knowledge Production from an African perspective: International information flows and intellectual property", The International Information \& Library review, 37, pp. 61-76. 
Luo, J., (2015). "Understanding the Implications of Ubiquitous Mobile Technology for Mature Adults in Post-PC Era Lifelong Learning", Concordia University, Master Thesis, http://spectrum.library.concordia.ca/979960/1/Luo_MA_S2015.pdf (Accessed: 26/07/2015).

Lwoga, E. T., Ngulube, P., \& Stilwell, C., (2010). "Managing indigenous knowledge for sustainable agricultural development in developing countries: Knowledge management approaches in the social context", The International Information \& Library Review, 42(3), pp. $172-185$.

Makinda, S. M., (2007). "How Africa can benefit from knowledge”, Futures, 39, pp. 973-985.

Marglin, S. A. (2013). “Premises for a New Economy”, Development, 56(2), pp. 149-154.

Maswera, T., Dawson, R., \& Edwards, J., (2008). "E-commerce adoption of travel and tourism organisations in South Africa, Kenya, Zimbabwe and Uganda", Telematics and Informatics, 25 (3), pp. 187-200.

Maurer, B. (2008, May). Retail electronic payments systems for value transfers in the developing world. Department of Anthropology, University of California.

McKenzie C, R., and McAleer M (1997). "On efficient estimation and correct inference in models with generated regressors: A general approach." Japanese Economic Review, 48(4), pp. 368-389.

Merritt, C. (2010, August). Mobile Money Transfer Services: The Next Phase in the Evolution in Person-to-Person Payments. Federal Reserve Bank of Atlanta, Retail Payments Risk Forum White Paper.

Moodley, S., (2003). "The Challenge of e-business for the South African apparel sector", Technovation, 23, pp. 557-570.

Monni, S., \& Spaventa, A., (2013). "Beyond GDP and HDI: Shifting the focus from paradigms to politics”, Development, 56(2), pp. 227-231.

Myburgh, A. F., (2011). "Legal developments in the protection of plant-related traditional knowledge: An intellectual property lawyer's perspective of the international and South African legal framework", South African Journal of Botany, 77, pp. 844-849.

Ndlovu-Gatsheni, S. J. (2013). "The Entrapment of African within the Global Colonial Matrices of Power: Eurocentrism, Coloniality and Deimperialieation in the Twenty-first century", Journal of Developing Societies, 29(4), pp. 331-353.

Neimark, B. D., (2012). "Industrializing nature, knowledge, and labour: The political economy of bioprospecting in Madagascar", Geoforum, 43, pp. 980-990.

Nyarko, Y., (2013). "Sustaining High Economic Growth in Sub-Saharan Africa: Knowledge and the Structure of the Economy", Journal of African Economies, 22, suppl_1(January), pp: -i101. 
Obeng-Odoom, F. (2013). "Africa's Failed Economic Development Trajectory: A Critique", African Review of Economics and Finance, 4(2), pp. 151-175.

Oluwatobi, S., Efobi, U., Olurinola, O. I., \& Alege, P., (2014). "Innovation in Africa: Why Institutions Matter", South African Journal of Economics, DOI: 10.1111/saje.12071.

Oluwatobi, S., \& Olurinola, O. I., (2015). "Mobile Learning in Africa: Strategy for Educating the Poor", Covenant University, Nigeria.

Ondiege, P. (2010). Mobile Banking in Africa: Taking the Bank to the People. Africa Economic Brief, 1(8), 1-16.

Oxley L, and McAleer, M., (1993). "Econometric issues in macroeconomic models with generated regressors." Journal of Economic Surveys, 7(1), pp. 1-40.

Oyelaran-Oyeyinka, B., \& Sampath, P. G., (2007). "Innovation in African Development. Case Studies of Uganda, Tanzania and Kenya", A World Bank Study. http://info.worldbank.org/etools/docs/library/239730/InnovationInAfricaFinalPaper.pdf (Accessed: 22/03/2014).

Pagan, A., (1984). "Econometric issues in the analysis of regressions with generated regressors" International Economic Review, 25(1), pp. 221-247.

Page, J., \& Shimeles, A., (2015). "Aid, Employment and Poverty Reduction in Africa", African Development Review, Supplement: Special Issue on "Aid and Employment”, 27,(S1), pp. 17-30.

Page, J., \& Söderbom, M., (2015). "Is Small Beautiful? Small Enterprise, Aid and Employment in Africa", African Development Review, Supplement: Special Issue on "Aid and Employment", 27,(S1), pp. 44-55.

Petrakis, P. E., \& Stamatakis, D. (2002). "Growth and educational levels: a comparative analysis". Economics of Education Review, 21 (2), pp. 513-521.

Penard, T., Poussing, N., Yebe, G. Z., \& Ella, P. N., (2012). "Comparing the Determinants of Internet and Cell Phone Use in Africa : Evidence from Gabon", Communications \& Strategies, 86, pp. 65-83.

Pesaran, M. H., (2006). "Estimation and inference in large heterogeneous panels with a multifactor error structure". Econometrica 74 (4), pp. 967-1012.

Preece, J., (2013). "Africa and international policy making for lifelong learning: textual revelations", International Journal of Educational Development, 33, pp. 98-105.

Quartey P., \& Afful-Mensah, G., (2014), Foreign Aid to Africa: Flows, Patterns and Impact, in Monga C and Lin J (eds), Oxford Handbook of Africa and Economics, Volume 2: Policies and Practices, Oxford University Press, Oxford, UK. 
Raseroka, K., (2008). "Information transformation Africa: Indigenous knowledge - Securing space in the knowledge society", The International Information and Library Review, 40, pp. 243250.

Rooney, D., (2005). "Knowledge, economy, technology and society: The politics of discourse", Telematics and Informatics, 22, pp. 405-422.

Simpasa, A, Shimeles, A., \& Salami, A. O., "Employment Effects of Multilateral Development Bank Support: The Case of the African Development Bank", African Development Review, Supplement: Special Issue on “Aid and Employment”, 27,( S1), pp. 31-43.

Stock, J. H. and M. W. Watson (2002). "Forecasting using principal components from a large number of predictors". Journal of the American Statistical Association, 97 (460), pp.1167-1179.

Sumberg, J., (2005). "Systems of innovation theory and the changing architecture of agricultural research in Africa", Food Policy, 30 (1), pp. 21-41.

Tchamyou, S. V., (2015). “The Role of Knowledge Economy in African Business", Journal of the Knowledge Economy: Revised and Resubmitted.

Thacker, K. U. M \& Wright, G. A. N. (2012, January). Building Business Models for Money. MicroSave Briefing Note No.116.

Thoburn, J., (2013). "Vietnam as a Role Model for Development", In Achieving Development Success: Strategies and Lessons from the Developing World, ed. Fosu, A., Oxford University Press.

Titumir, R. A. M., \& Kamal, M. (2013). "Growing Together Sustainably: A zero-poverty post 2015 development framework", Development, 56(2), pp. 172-184.

Tuijnman, A., (2003). "Measuring Lifelong Learning for the New Economy", Compare: A Journal of Comparative and International Education, 33(4), pp. 471-482.

Wa Gĩthĩnji, M., \& Adesida, O., (2011). "Industrialization, Exports and the Developmental State in Africa: The Case for Transformation", University of Massachusetts Amberst, Department of Economics Working Paper, No. 2011-18.

Wagiciengo, M. M., \& Belal, A. R., (2012). "Intellectual capital disclosure by South African companies: A longitudinal investigation”, Advances in Accounting, 28 (1), pp. 111-119.

Wamboye, E., Adekola, A., \& Sergi, B. S. (2013). "Economic Growth and the Role of Foreign Aid in Selected African Countries", Development, 56(2), pp. 155-171.

Weber, A. S., (2011). "The role of education in knowledge economies in developing countries", Procedia Social and Behavioral Sciences, 15, pp. 2589-2594. 
Westerlund, J., and Urbain, J-P., (2013a). "On the estimation and inference in factor-augmented panel regressions with correlated loadings", Economic Letters, 119, pp. 247-250.

Westerlund, J., and Urbain, J-P., (2013b). “On the implementation and use of factor-augmented regressions in panel data”, Journal of Asian Economics, 28, pp. 3-11.

Westerlund, J., and Urbain, J-P., (2012). "Cross-sectional averages versus principal components", Maastricht University, RM/11/053.

Word Bank (2015). "World Development Indicators', World Bank Publications

http://www.gopa.de/fr/news/world-bank-release-world-development-indicators-2015 (Accessed: 25/04/2015).

Zerbe, N., (2005). "Biodiversity, ownership, and indigenous knowledge: exploring legal frameworks for community, farmers, and intellectual property rights in Africa", Ecological Economics, 53, pp. 493-506. 